\title{
Management of non-tubal ectopic pregnancies associated with cervical and uterine canal: single-centre eight-year experience
}

\section{Servikal ve uterin kanal ile ilişkili tubal olmayan ektopik gebeliklerin yönetimi: tek merkez sekiz yıllık deneyim}

\author{
Seyhun SUCU1@(D), Hüseyin Çağlayan ÖZCAN ${ }^{1}$ (D) \\ ${ }^{1}$ Gaziantep University, School of Medicine, Department of Obstetrics and Gynecology, 27310, Gaziantep-Turkey
}

Atıf gösterme/Cite this article as: Sucu S, Özcan HÇ. Management of non-tubal ectopic pregnancies associated with cervical and uterine canal: single-centre eight-year experience. ADYÜ Sağllk Bilimleri Derg. 2021;7(3):183-191. doi:10.30569.adiyamansaglik.916189

\begin{abstract}
Aim: To discuss the diagnosis and treatment of nontubal ectopic pregnancies (NTEP) associated with the cervical and uterine canal.

Materials and Methods: In this cross-sectional retrospective study, we analyzed our hospital records in terms of cervical, angular (or cornual), scar, and cervico-isthmic NTEP from 2009 to 2017 and identified 112 cases between 5 and 13 weeks.

Results: There were 70, 20, 17, and 5 women in the scar, cervical, angular (or cornual), and cervico-isthmic ectopic pregnancy groups; respectively.

The gravity, parity, postoperative hospital stay length, admission complaints, previous cesarean section and treatment methods were compared among the four groups, a significant difference was found.

Conclusion: The surgical approach can be considered as the first-line treatment option in NTEP associated with the cervical and uterine canal. Due to the high potential for complications, early diagnosis and timely referral to tertiary health centres are crucial.

Keywords: Angular pregnancy; Cervical pregnancy; Cervico-isthmic pregnancy; Ectopic pregnancy; Scar pregnancy.
\end{abstract}

Öz

Amaç: Servikal ve uterin kanal ile ilişkili tubal olmayan ektopik gebeliklerin (NTEP) tanı ve tedavisini tartışmak.

Gereç ve Yöntem: Bu kesitsel retrospektif çalışmada, 2009-2017 yılları arasındaki servikal, açısal (veya kornual), skar ve servikoistmik gebelikleri hastane kayıtlarımızdan araştırdık ve 5-13 hafta arasında 112 vaka belirledik.

Bulgular: Skar, servikal, açısal (veya kornual) ve servikoistmik ektopik gebelik gruplarında sırasıyla 70 , 20, 17 ve 5 kadın vardı. Dört grup arasında gravite, parite, postoperatif hastanede kalış süresi, başvuru şikayetleri, önceki sezaryen ve tedavi yöntemleri karşılaştırıldığında, anlamlı fark bulundu.

Sonuç: Servikal ve uterus kanalı ile ilişkili NTEP'de cerrahi yaklaşım birinci basamak tedavi seçeneği olarak düşünülebilir. Yüksek komplikasyon potansiyeli nedeniyle erken teşhis ve üçüncü basamak sağlık merkezlerine zamanında sevk çok önemlidir.

Anahtar Kelimeler: Angular gebelik; Servikal gebelik; Serviko-istmik gebelik; Skar gebelik; Ektopik gebelik.

Yazışma Adresi/Address for Correspondence: Seyhun SUCU, Gaziantep University, School of Medicine, Department of Obstetrics and Gynecology, 27310, Gaziantep-Turkey, E-mail: sucuseyhun@gmail.com

Geliş Tarihi/Received:15.04.2021 Kabul Tarihi/Accepted:01.11.2021 Yayım Tarihi/Published online:31.12.2021 


\section{Introduction}

Ectopic pregnancy has always been one of the leading direct causes of maternal morbidity and mortality. Our understanding and knowledge of abnormally located pregnancies are improving due to both advances in ultrasound technology and the growing body of scientific data. Non-tubal ectopic pregnancies (NTEP) are a relatively new group and account for $7-10 \%$ of all ectopic pregnancies. There is an ongoing debate about their definition, and different terms are used, such as "cervico-istmatic", "cornual", "interstitial" and "angular" pregnancies. NTEP reveal a real challenge for the clinician in diagnosis and management, which are associated with higher morbidity due to their late recognition and diagnosis. ${ }^{1}$

In this report, we suggest comprehensive classifications that cervical, cervico-isthmic, angular (or cornual), and cesarean scar pregnancy (CSP) are members of a cervical and uterine canal located subgroup of NTEP. We aimed to discuss the diagnosis and management NTEP in the cervical and uterine canal and summarize eight years of experience at a single centre.

\section{Materials and Methods}

We retrospectively analyzed our hospital records in terms of cervical, scar, angular (or cornual), and cervico-isthmic NTEP from 2009 to 2017 at the department of obstetrics and gynaecology of a university hospital. Demographic and clinical data were obtained for all women.

We classified NTEP according to their location in or out of the cervical and uterine canal (Table 1). If an ultrasound examination reveals a barrel-shaped cervix, an empty uterine cavity, a gestational sac located under the border of the uterine arteries, and an absence of the sliding sign (there is no displacement of gestational sac if the clinician pushes the vaginal probe toward the cervix) cervical ectopic pregnancy (Figure 1A) can be diagnosed. ${ }^{2,3}$
Table 1. Proposed classification of ectopic pregnancies.

\begin{tabular}{l}
\hline A. Tubal ectopic pregnancies: \\
\hline 1. Interstitial \\
2. Isthmic \\
3. Ampullary \\
4. Fimbrial \\
\hline B. Non-tubal ectopic pregnancies: \\
\hline 1. Related to the cervical and uterine canal \\
I. Cervical \\
II. Cervico-isthmic \\
III. Uterine scar \\
IV. Angular (normal uterus) or Cornual \\
(abnormal uterus) \\
2. Out of the cervical and uterine canal \\
I. Abdominal \\
II. Ovarian
\end{tabular}

Angular or cornual pregnancy can be defined as implantation of the embryo near to the internal ostium of the fallopian tube in the superolateral corner of the uterine cavity. ${ }^{1}$ Ultrasonographic characteristics of an angular (or cornual) pregnancy include a gestational sac at an eccentric location close to the internal uterine ostium of the fallopian tube, primarily surrounded by endometrium with the adjacent thick myometrial layer (Figure 1B). ${ }^{4}$ Cervico-isthmic ectopic pregnancy (Figure 1C) has three standard features including 1) Gestational sac located in both the corpus and the internal cervical os 2) Well-preserved and closed cervical canal 3) An empty fundal zone in the upper half of uterine cavity. ${ }^{5}$ Scar pregnancy has five characteristics on transvaginal ultrasound including (1) there should be no pregnancy product in the uterus and cervix; (2) the pregnancy must have located on the anterior wall of the isthmic region; (3) Continuity of the anterior uterine wall is not observed in the sagittal plane where the amniotic sac can be seen; (4) the myometrial layer above the gestational sac is too thin (1-3 mm) or absent (Figure 1D), and (5) In Doppler evaluation, the high velocity with low impedance vascular flow should monitor nearby the gestational sac. ${ }^{6}$ Patients with CSP underwent two different surgical methods including trans abdominal ultrasound (TAUS) guided suction curettage and hysterotomy. We performed suction curettages with 6-8 $\mathrm{mm}$ Karman cannulas under mask anaesthesia and in the dorsal lithotomy position. General anaesthesia was preferred in all 
hysterotomies. The determination of the surgical method to be selected as the primary treatment in our study was dependent on the thickness of the myometrial tissue between the bladder and gestational sac and the severity of vascular invasion. As mentioned in our previous study (consisted of only CSP patients) ${ }^{7}$; suction curettage was preferred in patients with hemodynamically stable, myometrial thickness $\geq 3 \mathrm{~mm}$ and without vascular invasion. Hysterotomy was preferred in patients with myometrial thickness $<3 \mathrm{~mm}$, vascular invasion and hemodynamically unstable patients (Table 2). We applied an 18F Foley catheter (inflated with roughly10-30 $\mathrm{ml}$ saline in the aspirated gestational sac zone) to achieve hemostasis in patients with
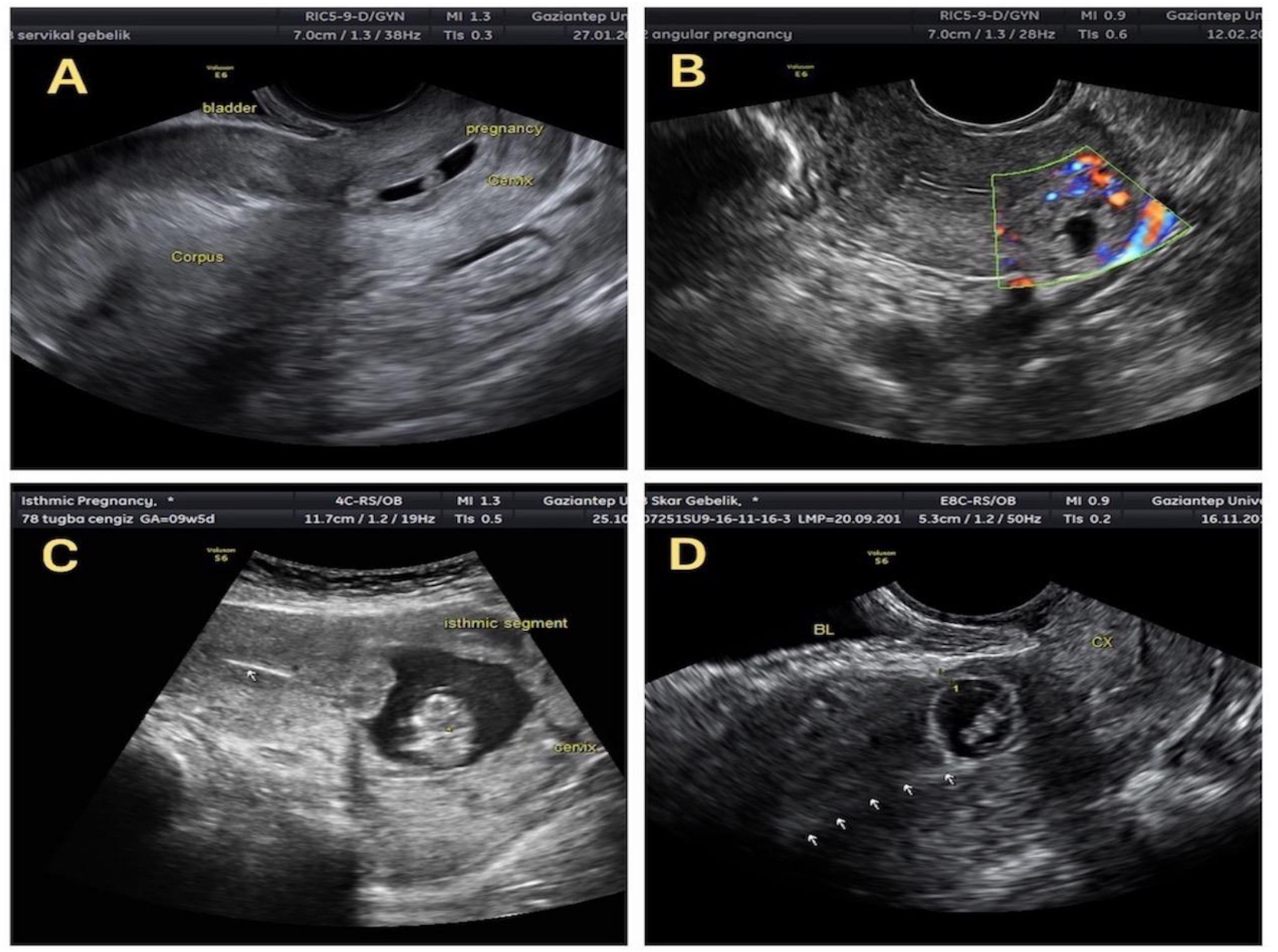

Figure 1. Ultrasonographic images of non-tubal ectopic pregnancies associated with cervical and uterine canal; A) cervical ectopic pregnancy, B) angular ectopic pregnancy, C) cervico-isthmic ectopic pregnancy demonstrates the fetus with an asterisk and empty upper half of endometrial cavity with an arrow, D) cesarean scar ectopic pregnancy in which the underlying healthy myometrium is $2.20 \mathrm{~mm}$ (BL: bladder; CX: cervix; and arrows indicating endometrial cavity).

\section{Ethics committee approval}

The study was approved by the local ethics committee of Gaziantep University (2017/116). persistent bleeding after suction curettage. In general, mode of surgical management and the course of methotrexate (MTX) therapy including single-dose or multiple-dose regimens, were recorded. The same gynecologic team performed all the surgeries, and informed consent was obtained from all women or their close relatives. If there was a decrease of less than $15 \%$ in $\beta$-hCG compared to preoperative levels at the postoperative 24th hour, we administered MTX therapy following the surgery. All specimens obtained were sent for pathological examination in order to confirm the diagnosis. After discharge, all women were followed up weekly and the level of $\beta$-hCG was monitored until the result is below limits. 
compare continuous variables with normal distribution between the groups. MannWhitney test was used when comparing two groups for non-normal data, and KruskalWallis and Dunn tests were used when comparing more than two groups. One-way ANOVA and LSD tests analyzed differences in variables showing normal distribution between the groups. The Chi-square test was utilized to evaluate the comparison of categorical variables. SPSS ${ }^{\circledR} 22.0$ Windows version was used for data analysis. $p<0.05$ value was accepted statistically significant.

Table 2. Suggested criteria of trans-abdominal ultrasound-guided suction curettage vs. hysterotomy for treatment of cesarean scar pregnancy.

\begin{tabular}{lcc}
\hline & Suction-Curettage & Hysterotomy \\
\hline $\begin{array}{l}\text { Ultrasound criteria } \\
\text { - } \quad \begin{array}{l}\text { Myometrial thickness between the bladder and } \\
\text { gestational sac }\end{array}\end{array}$ & $\geq 3 \mathrm{~mm}$ & $<3 \mathrm{~mm}$ \\
$\bullet \quad$ Presence of vascular invasion & No & Yes \\
\hline $\begin{array}{l}\text { Clinical and Laboratory criteria } \\
\bullet \quad \text { Hemodynamically stable }\end{array}$ & Yes & No \\
\hline
\end{tabular}

\section{Results}

There were 112 NTEP cases related to the cervical and uterine canal, including 70 CSP, 20 cervical, 17 angular (or cornual), and five cervico-isthmic pregnancies during the study period. A hundred and four cases (93\%) underwent surgical treatment, and $8(7 \%)$ underwent surgical with medical treatment. Eighty-one cases (72\%, 81/112) were transferred from another health institution to our hospital. The comparison of maternal features and outcomes of the four groups are shown in Table 3. The gravity, parity, postoperative hospital stay length, admission complaints, previous cesarean section (CS) and treatment methods were compared among the four groups, a significant difference was found.

Table 3. The comparison of maternal characteristics and outcomes of four groups.

\begin{tabular}{|c|c|c|c|c|c|}
\hline Variables & $\begin{array}{l}\text { Scar } \\
\text { Pregnancy } \\
(\mathrm{N}=70)\end{array}$ & $\begin{array}{l}\text { Pregnancy } \\
(\mathrm{N}=\mathbf{2 0})\end{array}$ & $\begin{array}{l}\text { Angular } \\
\text { /Cornual } \\
\text { Pregnancy } \\
(\mathbf{N}=17)\end{array}$ & $\begin{array}{l}\text { Cervico-isthmic } \\
\text { Pregnancy } \\
(\mathrm{N}=5)\end{array}$ & $p$ \\
\hline Age (year) * & $32.74 \pm 4.93$ & $33.2 \pm 6.21$ & $30.29 \pm 5.7$ & $31.8 \pm 8.47$ & 0.362 \\
\hline Gravidity $\uparrow$ & $4[2-11]^{A}$ & $3[1-13]^{\mathrm{B}}$ & $4[1-6]^{\mathrm{B}}$ & $4[2-6]^{\text {A. B }}$ & $0.017 * *$ \\
\hline Parity $\dagger$ & $3[1-7]^{A}$ & $2[0-9]^{\text {A. B }}$ & $1[0-4]^{\mathrm{B}}$ & $2[1-5]^{\text {A. B }}$ & $0.005 * *$ \\
\hline Gestational age (day) * & $48.99 \pm 8.82$ & $56.6 \pm 16.29$ & $53.12 \pm 11.88$ & $59 \pm 21.77$ & 0.133 \\
\hline Hospital stay (day) * & $1.66 \pm 1.28^{\mathrm{B}}$ & $1.5 \pm 1.28^{\mathrm{B}}$ & $2.35 \pm 1.5^{\mathrm{A}}$ & $2.2 \pm 1.3^{\text {A. B }}$ & $0.005 * *$ \\
\hline Erythrocyte suspension * & $0.2 \pm 0.84$ & $0.2 \pm 0.89$ & $0.24 \pm 0.66$ & $0.8 \pm 1.79$ & 0.555 \\
\hline Initial $\beta$-hCG * & $\begin{array}{l}18969.53 \pm \\
15888.28\end{array}$ & $\begin{array}{l}24638.55 \pm \\
28785.38\end{array}$ & $\begin{array}{l}18056.35 \pm \\
15415.15\end{array}$ & $\begin{array}{l}20775 \pm \\
24689.22\end{array}$ & 0.940 \\
\hline Complaint + & & & & & $0.001 * *$ \\
\hline $\begin{array}{l}\text { Pelvic pain + Vaginal } \\
\text { bleeding }\end{array}$ & $6(8.6 \%)$ & $2(10.0 \%)$ & $5(29.4 \%)$ & $1(20.0 \%)$ & \\
\hline Pelvic pain & $8(11.4 \%)^{\mathrm{B}}$ & $3(15.0 \%)$ & $9(52.9 \%)^{\mathrm{A}}$ & $1(20.0 \%)$ & \\
\hline Vaginal bleeding & $27(38.6 \%)$ & $8(40.0 \%)$ & $0(0.0 \%)$ & $3(60.0 \%)$ & \\
\hline Complication $\div$ & $2(2.9 \%)$ & $1(5.0 \%)$ & $0(0.0 \%)$ & $1(20.0 \%)$ & 0.364 \\
\hline $\begin{array}{l}\text { Presence of fetal heart } \\
\text { activity } \ddagger\end{array}$ & $22(31.4 \%)$ & $6(30.0 \%)$ & $6(35.3 \%)$ & $1(20.0 \%)$ & 0.927 \\
\hline History of previous CS $\$$ & $70(100 \%)^{A}$ & $13(65.0 \%)^{\mathrm{B}}$ & $6(35.3 \%)^{\mathrm{B}}$ & $5(100.0 \%)^{\text {А. В }}$ & $0.001 * *$ \\
\hline Treatment modality $\$$ & & & & & $0.001 * *$ \\
\hline Surgery alone & $70(100.0 \%)$ & $14(70.0 \%)$ & $15(88.2 \%)$ & $5(100.0 \%)$ & \\
\hline Medical + Surgery & $0(0.0 \%)^{\mathrm{B}}$ & $6(30.0 \%)^{A}$ & $2(11.8 \%)^{\mathrm{B}}$ & $0(0.0 \%)^{\mathrm{B}}$ & \\
\hline
\end{tabular}

$*$ Mean \pm Std. deviation, $\dagger$ Median $[25 \%-75 \%], \ddagger N(\%)$

$\mathrm{A}, \mathrm{B}$ : A is significantly higher than $\mathrm{B}, * * p<0,05$ value is significant 
We performed wedge resection, D\&C alone, and administered adjuvant multidose MTX regimen following $\mathrm{D} \& \mathrm{C}$ in $13,2,2$ patients with angular (or cornual) pregnancy group; respectively. Three patients had been referred with uterine rupture before surgery in the angular (or cornual) pregnancy group. There was a history of ectopic pregnancy in 2 women, a history of tuboplasty in one patient, and two women who had uterine abnormality (bicornuate uterus) in the angular (or cornual) pregnancy group. Of the 70 patients with CSP, 57 patients $(81 \%)$ performed suction curettage and 13 patients (19\%) performed hysterotomy. There was one uterine rupture in the suction curettage group and one bladder injury in the abdominal hysterotomy group. Four of the 57 patients in the vacuum curettage group had permanent bleeding, and successful hemostasis was achieved by applying a Foley catheter to these patients. The comparison of treatment modalities is presented in Table 4. There was a significant difference between the two groups when we compared the duration of the $\beta$-hCG resolution. Pathological reports of all specimens that were sent for examination was consistent with the presumed diagnosis. Seventy-three $(65 \%)$ of 112 women had vaginal bleeding or pelvic pain complaint on admittance to our clinic. Vaginal bleeding was observed in 38 women (52\%), and this was the most common complaint. Only eight of 112 patients required transfusion of erythrocyte suspension following the surgical treatments. Seven patients needed replacement of erythrocyte suspension in the surgical group (4 units per 5 patients and two units per 2 patients) and one in surgery with the medical group ( 2 units). Three patients needed intensive care unit, including one patient with cervical pregnancy and two patients with CSP.

Table 4. The comparison of treatment modalities.

\begin{tabular}{|c|c|c|c|}
\hline Variables & $\begin{array}{l}\text { Surgery Alone } \\
(\mathrm{N}=104)\end{array}$ & $\begin{array}{c}\text { Medical + Surgery } \\
(\mathrm{N}=8)\end{array}$ & $p$ \\
\hline Presence of complication $\$$ & $4(3.8 \%)$ & $0(0.0 \%)$ & 0.339 \\
\hline Hospital stay (day) * & $1.71 \pm 1.24$ & $2.37 \pm 2.26$ & 0.847 \\
\hline Erythrocyte suspension * & $0.23 \pm 0.89$ & $0.25 \pm 0.71$ & 0.586 \\
\hline Initial $\beta$-hCG * & $19733.32 \pm 18820.83$ & $21542.75 \pm 22249.89$ & 0.888 \\
\hline $\begin{array}{l}\text { Duration to resolution of } \\
\beta \text {-hCG (day) * }\end{array}$ & $18.85 \pm 8.14$ & $23.62 \pm 7.07$ & $0.048 * *$ \\
\hline
\end{tabular}

\section{Discussion}

There is a lack of consensus on the terminology of lesser forms of ectopic pregnancies other than tubal types. This lack of a generally accepted consensus results in different terminologies regarding the same pathologies and makes the assessment of different management options more complicated. NTEP has severe consequences, including maternal morbidity, maternal mortality, and potential problems associated with future fertility. ${ }^{1}$ The diagnosis and treatment of NTEP are challenging and frequently constitute a medical emergency. In this article, we used a comfortable and anatomically oriented classification for NTEP (Table 1). We focused on a specific subgroup of NTEP in which the pregnancy is located in the cervical and uterine canal. In this subgroup of NTEP, the gestation is within the uterine cavity, and therefore management can be based on surgical methods alone, mostly when an early diagnosis is made.

There is a considerable amount of confusion and also a scarcity of definitive publications when using the terms "interstitial", "cornual" and "angular" pregnancies. Interstitial pregnancy should be carefully differentiated owing to the high risk for rupture and subsequent life-threatening complications. A cornual pregnancy, or more recently named 'angular' pregnancy, can be defined as a pregnancy in the superolateral region of the uterine cavity whether the uterus is normal or has a Mullerian duct abnormality. ${ }^{8}$ The merit for using cornual or angular terminology is for giving information regarding uterine morphology. Therefore, we 
propose the term "cornual pregnancy" when there is a uterine abnormality and "angular pregnancy" when the uterine anatomy is normal. There were two women with cornual pregnancy coexisting with a uterine abnormality (bicornuate uterus) in our study. Exact anatomical location can be defined as "implantation within the endometrium of the lateral angle of the uterus, medial to the utero tubal junction", which is contradictory with the classic definition of ectopic pregnancy. ${ }^{9}$ Although an angular pregnancy is a potentially viable one, the risk of abortion $(38.5 \%)$ or more seriously uterine rupture $(13.6 \%)$ is relatively higher than a normal intrauterine pregnancy. ${ }^{10}$ The seriousness of the latter is strong support for the rationale of the proposed classification of angular (or cornual) pregnancy as a subgroup of ectopic pregnancy in our paper. Angular (or cornual) pregnancy is within the endometrium at the end of the uterine canal, but clinicians should manage this disease as an ectopic pregnancy.

Another crucial clinical dilemma is differentiating an angular (or cornual) pregnancy from an interstitial one. The primary hallmark of the latter is that it lies in the myometrial portion of the tube continuously surrounded by the myometrial wall of the uterus and carries certain ultrasonographic features such as interstitial line sign. ${ }^{11}$ Women with angular (or cornual) pregnancy usually have complaints following eight weeks' gestation due to myometrial extensibility. ${ }^{12}$ Interestingly in our study, a rupture was already present at the cornual region in three cases with angular (or cornual) pregnancy before eight weeks and the only one after eight weeks. A ruptured angular (or cornual) ectopic pregnancy is a real surgical emergency that can be differentiated from a ruptured interstitial pregnancy by observation of an intact proximal uterine tube. The treatment options include cornuostomy, cornual wedge resection, or hysterectomy either with laparoscopy or laparotomy. ${ }^{12}$ Also, the hysteroscopic route can be performed in cornual wedge resection. ${ }^{13}$ There are few reports in the literature implicating the success of medical management of cornual pregnancy in case of early and rapid diagnosis (especially in women with hCG concentration less than $5000 \mathrm{mIU} / \mathrm{mL}) .{ }^{14}$ Our data suggest that surgical therapy, as a first-line choice, is safe in these women. We carried out cornual wedge resection (13/17), D\&C alone (2/17), and administered adjuvant multidose MTX regimen following $\mathrm{D} \& \mathrm{C}(2 / 17)$ when there was suspicious sonographic image suggesting incomplete removal of cornual trophoblastic tissues or in the event of reduction less than $15 \%$ in $\beta$-hCG levels. Some authors suggested conservative methods in selective cases of interstitial or angular (or cornual) pregnancies, but these methods carry a high risk of failure if patients are unstable and have high $\beta$-hCG levels. ${ }^{15}$

In cervical pregnancy, trophoblastic tissue develops a detrimental effect on the fibrous cervical wall. This kind of NTEP is associated with a history of CS, intrauterine device (IUD), and repeated D\&C. ${ }^{16}$ Also, our study demonstrated that history of previous CS is positively associated with cervical pregnancy as compared to angular (or cornual) and cervico-isthmic pregnancy. In the early period of cervical pregnancy, women usually present with frequent vaginal haemorrhage without pain, but in the advanced weeks of gestation, supplementary complaints like abdominal pain and urinary problems accompany vaginal haemorrhage. ${ }^{16}$ In our study, all these above symptoms were present, but the most common symptom was vaginal bleeding (40\%). Conservative medical and surgical management is the most preferred treatment modality in cervical pregnancy, while hysterectomy should be performed following the first trimester in women with intractable bleeding. ${ }^{1} \mathrm{D} \& \mathrm{C}$ is useful either in extracting the products of gestation or ceasing vaginal bleeding and can be performed both as a single treatment and as adjuvant therapy. ${ }^{17,18}$ We performed D\&C in 12 of 20 women and administered adjuvant methotrexate in 6 women when there was a suspicious sonographic image suggesting incomplete removal of cervical trophoblastic tissues that may lead to intractable bleeding. This approach for adjuvant therapy can be advocated for both cervical and angular (or cornual) pregnancies. In our study, the 
duration of the resolution of $\beta$-hCG in such cases was significantly longer. Numerous treatment options are suggested, but none of them could be considered as an optimal approach in the treatment of cervical ectopic pregnancy. ${ }^{19}$ Early diagnoses in cervical ectopic pregnancy cases are crucial, and MTX resistance is generally present in advanced pregnancy cases with $\beta$-hCG values greater than $5000 \mathrm{mIU} / \mathrm{mL}^{20}$ In our study, the majority of women with cervical pregnancy $(18 / 20)$ presented with $\beta$-hCG levels higher than $5000 \mathrm{mIU} / \mathrm{mL}$. There is a considerable debate on the use of surgical approaches, especially $\mathrm{D} \& \mathrm{C}$, as the first treatment option. Some authors proposed that D\&C should not be the first-line approach in cervical and caesarean scar pregnancy because of the risk of perforation and catastrophic haemorrhage. ${ }^{21}$ Although the limited study size with cervical pregnancy, our results suggest that $\mathrm{D} \& \mathrm{C}$ may be a reliable first-line option in the management of cervical pregnancy when performed by experienced surgeons guided with sonographic imaging. There are many adjuvant therapies including, angiographic uterine artery embolization, intra-cervical vasopressin injection, ligation of the cervical branches of the uterine arteries, performing Shirodkar-type cerclage, and balloon tamponade in case of severe haemorrhage. ${ }^{22}$ Flystra described a new technique with encouraging results, including the combination of vasopressin injection and untied McDonald cerclage before performing D\&C and balloon tamponade. ${ }^{23} \mathrm{We}$ successfully managed 20 cervical pregnancy cases with D\&C, except for three cases, in which we inserted and inflated a Foley catheter in two cases to avoid the intractable bleeding, and we caused a complication (bladder injury) in one patient. Adjuvant single and multidose MTX was administered after D\&C in four and two cases, respectively. There are some limitations of using medical therapy alone, including the necessity for careful patient counselling, extended recovery period and close tracking of these women due to the risk of rupture and haemorrhage. ${ }^{24}$ Because of concerns as mentioned above and emergent status (vaginal bleeding) of presented patients in our study, we did not consider using medical therapy alone.

Cervico-isthmic pregnancy can be defined as a gestational sac locating in the uterine isthmus, which is the region between the histologic internal and the anatomical internal ostia. ${ }^{25}$ There is no sufficient publication neither for the diagnosis nor the management of cervico-isthmic pregnancy in the literature. Strobelt et al. ${ }^{5}$ and Oyelese et al. ${ }^{25}$ suggested that the gestational sac is located in both the corpus and the internal cervical os, and a well-preserved and closed cervical canal is observed in a cervico-isthmic pregnancy, while the sac is not present in the fundal zone. There is no consensus regarding the management of cervico-isthmic pregnancies. The patient with cervico-isthmic pregnancy should be informed about risks of profuse bleeding and hysterectomy at birth, and also a need close follow-up throughout the pregnancy. ${ }^{5,26}$ The need for qualified research for both definition and management is evident. The management uncertainty is the merit of differentiating cervico-isthmic and cervical pregnancies, which should be the focus of future research. We preferred to manage the five cervico-isthmic pregnancy cases with surgery alone ( $2 \mathrm{D} \& \mathrm{C}$ and three hysterotomies) and had to perform a hysterectomy to stop intractable bleeding in one patient.

The caesarean delivery (CS) incidence has increased from $21.2 \%$ in 2001 to $46.7 \%$ in 2011 over the last decades in Turkey. ${ }^{27}$ This finding can be the possible reason for the high rate of patients with CSP $(62.5 \%, 70 / 112)$ in our study. Although many studies have reported that surgical treatment should be the first option in CSP, there is still no consensus on this issue. The advantages of the surgical approach include complete resection of trophoblastic tissue, reduction of uterine rupture and haemorrhage, and minimize the need for additional treatment after the procedure. ${ }^{28}$ Birch Petersen et al. ${ }^{29}$ mentioned five different treatment modalities in the management of CSP which were transvaginal resection, laparoscopic resection, uterine artery embolization (UAE), UAE in combination with suction curettage, and hysteroscopic resection. The success rates of 
these treatment modalities were $99.2 \%$, $97.1 \%, \quad 95.4 \%, \quad 93.6 \%$ and $83.2 \%$, respectively. ${ }^{29}$ The success rates we revealed in our research were similar to previous studies and were over $90 \%$; the success rates of suction curettage and hysterotomy were $98.2 \%(56 / 57)$ and $92.3 \% \quad(12 / 13)$, respectively. Disadvantages of the surgical approach may include tissue damage, anaesthetic complications, abundant bleeding, prolonged recovery, and hospital stay. ${ }^{28}$ There are inconsistent data concerning which surgical method should be chosen in primary care in CSP management. On the one hand, some authors suggest that D\&C is not an appropriate treatment for CSP due to the higher risk of massive bleeding and uterine rupture. ${ }^{30-32}$ On the contrary, some advocate the aspiration curettage method, which can be performed with very few complications and is easy to apply. ${ }^{33,34}$ Myometrial thickness among ectopic pregnancy mass and bladder is a handy and informative tool to determine the treatment method. Various cut-off limits have been defined such as afore $2 \mathrm{~mm}{ }^{35}, 3,5 \mathrm{~mm}$ ${ }^{31}$, or $4,5 \mathrm{~mm} .{ }^{36}$ As described in our previous study ${ }^{7}$, we preferred TAUS-guided suction curettage alone when the myometrial thickness was $\geq 3 \mathrm{~mm}$. Additionally, we expanded the study size of CSP patients in the present study. There were intractable bleeding in four patients, but the implementation of a Foley catheter was adequate to cease the bleeding. In the TAUS-guided aspiration curettage group, we experienced a complication of uterine rupture treated with mini-laparotomy in only one case $(1.4 \%)$. Laparotomy should be preferred in patients with suspected uterine rupture. This practice may be the best treatment for CSP because it allows complete removal of the gestational sac and repair of the uterine wall and minimizes the risk of recurrence. However, it is related to major trauma, extended recovery times, and prolonged hospital stays. ${ }^{37} \mathrm{We}$ believe that when the myometrial thickness is less than $<3 \mathrm{~mm}$ and vascular invasion is suspected in doppler ultrasonography, hysterotomy should be preferred as the treatment method. On the other hand, in selected cases with hemodynamically stable, TAUS-guided aspiration curettage can be suggested as a first-line treatment option due to its low cost, ease of administration, low side effect profile, and potentially minimal impact on future fertility.

Retrospective nature is the major limitation of our study. Since it is a single-centre study, patient and treatment selection bias could not be excluded. The lack of conclusive data respecting how to choose an appropriate surgical approach in a given NTEP may lead to bias and may be considered another weakness of our study. The unique features of this study are its large study size and diagnosis and treatment practices being performed by the same gynecologic team.

\section{Conclusion}

In conclusion, our study shows that surgical treatment can be the first treatment option in NTEP associated with the cervical and uterine canal. The availability of supportive facilities in tertiary centres is a critical factor for success. Clinicians should be aware of the importance of early diagnosis, and patients should be referred to tertiary centres on time due to the high potential of complications.

\section{Ethics Committee Approval}

The study was approved by the local ethics committee of Gaziantep University (2017/116).

\section{Informed Consent}

All participants signed the Informed Consent Form and their consent was obtained.

\section{Author Contributions}

SS carried out the study, performed the surgical procedures, followed up the patients, and contributed to the first draft of the paper. HCÖ revised the manuscript critically for important intellectual content, wrote the manuscript and finalized the paper.

\section{Acknowledgements}

The authors thank Tanyeli Güneyligil Kazaz for her help in statistical analysis.

\section{Conflict of Interest}

The authors declare that they have no conflict of interest. 


\section{Financial Disclosure}

The authors declared that this study received no financial support.

\section{Peer-review}

\section{Externally peer-reviewed.}

\section{References}

1. Long Y, Zhu H, Hu Y, Shen L, Fu J, Huang W. Interventions for non-tubal ectopic pregnancy. Cochrane Database Syst Rev. 2020; 7. Art. No.: CD011174. DOI: 10.1002/14651858.CD011174.pub2.

2. Jurkovic D, Hacket E, Campbell S. Diagnosis and treatment of early cervical pregnancy: a review and a report of two cases treated conservatively. Ultrasound Obstet Gynecol. 1996;8(6):373-380.

3. Kirk E, Bottomley C, Bourne T. Diagnosing ectopic pregnancy and current concepts in the management of pregnancy of unknown location. Hum Reprod Update. 2014;20(2):250-261.

4. Arleo EK, DeFilippis EM. Cornual, interstitial, and angular pregnancies: clarifying the terms and a review of the literature. Clin Imaging. 2014;38:(6)763-770.

5. Strobelt N, Locatelli A, Ratti M, Ghidini A. Cervico-isthmic pregnancy: a case report, critical reappraisal of the diagnostic criteria, and reassessment of the outcome. Acta Obstet Gynecol Scand. 2001;80(6):586-588.

6. Timor-Tritsch IE, Monteagudo A. Unforeseen consequences of the increasing rate of cesarean deliveries: early placenta accreta and cesarean scar pregnancy. A review. Am J Obstet Gynecol 2012;207(1):14-29.

7. Özcan HÇ, Uğur MG, Balat Ö, Sucu S, Mustafa A, Tepe NB, et al. Is ultrasound-guided suction curettage a reliable option for treatment of cesarean scar pregnancy? A cross-sectional retrospective study. $J$ Matern Neonatal Med. 2018;31(22):2953-2958.

8. F. Cunningham, Kenneth Leveno, Steven Bloom, John Hauth, Dwight Rouse CS. Williams Obstetrics. 23rd Edition. 2009.

9. Parker RA, Yano M, Tai AW, Friedman M, Narra VR, Menias CO. MR imaging findings of ectopic pregnancy: A pictorial review. Radiographics. 2012;32(5):1445-1460.

10. Moawad NS, Mahajan ST, Moniz MH, Taylor SE, Hurd WW. Current diagnosis and treatment of interstitial pregnancy. Am J Obstet Gynecol. 2010;202(1):15-29.

11. Ackerman TE, Levi CS, Dashefsky SM, Holt SC, Lindsay DJ. Interstitial line: sonographic finding in interstitial (cornual) ectopic pregnancy. Radiology. 1993;189(1):83-87.

12. Ng S, Hamontri S, Chua I, Chern B, Siow A. Laparoscopic management of 53 cases of cornual ectopic pregnancy. Fertil Steril. 2009;92(2):448-452.

13. Pal B, Akinfenwa O, Harrington K. Hysteroscopic management of cornual ectopic pregnancy. BJOG An Int J Obstet Gynaecol. 2003;110(9):879-880.

14. Lau S, Tulandi T. Conservative medical and surgical management of interstitial ectopic pregnancy. Fertil Steril. 1999;72(2):207-215.

15. Bernstein H. Expectant management of intramural ectopic pregnancy. Obstet Gynecol. 2001;97(5 Pt 2):826-827.

16. Shan N, Dong D, Deng W, Fu Y. Unusual ectopic pregnancies: A retrospective analysis of 65 cases. J Obstet Gynaecol Res. 2014;40(1):147-154.

17. Marchiolé P, Gorlero F, De Caro G, Podesta M, Valenzano M. Intramural pregnancy embedded in a previous Cesarean section scar treated conservatively. Ultrasound Obstet Gynecol. 2004;23(3):307-309.

18. Jurkovic D, Hillaby K, Woelfer B, Lawrence A, Salim R, Elson CJ. First-trimester diagnosis and management of pregnancies implanted into the lower uterine segment Cesarean section scar. Ultrasound Obstet Gynecol. 2003;21(3):220-227.

19. Chetty M, Elson J. Treating non-tubal ectopic pregnancy. Best Pract Res Clin Obstet Gynaecol. 2009;23(4):529-538.

20. Alkatout I, Honemeyer U, Strauss A, Tinelli A, Malvasi A, Jonat W, et al. Clinical Diagnosis and Treatment of Ectopic Pregnancy. Obstet Gynecol Surv. 2013;68(8):571-581.

21. Litwicka K, Greco E. Caesarean scar pregnancy. Curr Opin
Obstet Gynecol. 2011;23(6):415-421.

22. Parker VL, Srinivas M. Non-tubal ectopic pregnancy. Arch Gynecol Obstet. 2016;294(1):19-27.

23. Fylstra DL. Cervical pregnancy: 13 cases treated with suction curettage and balloon tamponade. Am J Obstet Gynecol. 2014;210(6):581.e1-5.

24. Leeman LM, Wendland CL. Cervical Ectopic Pregnancy: Diagnosis With Endovaginal Ultrasound Examination and Successful Treatment With Methotrexate. Arch Fam Med. 2000;9(1):72-77.

25. Oyelese Y, Elliott TB, Asomani N, Hamm R, Napoli L, Lewis KM. Sonography and Magnetic Resonance Imaging in the Diagnosis of Cervico-Isthmic Pregnancy. J Ultrasound Med. 2003;22(9):981-983.

26. Honda T, Hasegawa M, Nakahori T, Maeda A, Sai R, Takata $\mathrm{H}$, et al. Perinatal management of cervicoisthmic pregnancy. $J$ Obstet Gynaecol Res. 2005;31(4):332-336.

27. Uzuncakmak C, Guldas A, Aydin S, Var A, Özçam H. Investigation of cesarean sections at Istanbul Training and Research Hospital Obstetrics and Gynecology Department between 2005 and 2012. Istanbul Med J. 2013;14(2):112-117.

28. Polat I, Ekiz A, Acar DK, Kaya B, Ozkose B, Ozdemir C, et al. Suction curettage as first-line treatment in cases with cesarean scar pregnancy: feasibility and effectiveness in early pregnancy. J Matern Neonatal Med. 2016;29(7):1066-1071.

29. Birch Petersen K, Hoffmann E, Rifbjerg Larsen C, Nielsen HS. Cesarean scar pregnancy: a systematic review of treatment studies. Fertil Steril. 2016;105(4):958-967.

30. Seow K-M, Huang L-W, Lin Y-H, Lin M Y-S, Tsai Y-L, Hwang J-L. Cesarean scar pregnancy: issues in management. Ultrasound Obstet Gynecol. 2004;23(3):247-253.

31. Wang Y-L, Su T-H, Chen H-S. Operative laparoscopy for unruptured ectopic pregnancy in a caesarean scar. BJOG An Int J Obstet Gynaecol. 2006;113(9):1035-1038.

32. Osborn DA, Williams TR, Craig BM. Cesarean Scar Pregnancy. J Ultrasound Med. 2012;31(9):1449-1456.

33. Jurkovic D, Knez J, Appiah A, Farahani L, Mavrelos D, Ross JA. Surgical treatment of Cesarean scar ectopic pregnancy: efficacy and safety of ultrasound-guided suction curettage. Ultrasound Obstet Gynecol. 2016;47(4):511-517.

34. Bignardi T, Condous G. Transrectal ultrasound-guided surgical evacuation of Cesarean scar ectopic pregnancy. Ultrasound Obstet Gynecol. 2010;35(4):481-485.

35. Tinelli A, Tinelli R, Malvasi A. Laparoscopic management of cervical-isthmic pregnancy: a proposal method. Fertil Steril. 2009;92(2):829.e3-829.e6.

36. Bayoglu Tekin Y, Mete Ural U, Balık G, Ustuner I, Kır Şahin F, Güvendağ Güven ES. Management of cesarean scar pregnancy with suction curettage: a report of four cases and review of the literature. Arch Gynecol Obstet. 2014;289(6):1171-1175.

37. Fylstra DL, Pound-Chang T, Miller MG, Cooper A, Miller KM. Ectopic pregnancy within a cesarean delivery scar: A case report. Am J Obstet Gynecol. 2002;187(2):302-304. 